\title{
The Oxidation of 2-(2-Methoxyethoxy)ethanol and 2-(2-Ethoxyethoxy)ethanol by Ditelluratocuprate(III): A Kinetic and Mechanistic Study
}

\author{
Jin-huan Shan, Yi Li, Shu-ying Huo, and Cai-hong Yin \\ College of Chemistry and Environmental Science, Hebei University, Baoding, Hebei 071002, China \\ Correspondence should be addressed to Jin-huan Shan; shanjinhuaner@yahoo.com.cn
}

Received 12 September 2012; Revised 26 December 2012; Accepted 1 January 2013

Academic Editor: Jose Corchado

Copyright (c) 2013 Jin-huan Shan et al. This is an open access article distributed under the Creative Commons Attribution License, which permits unrestricted use, distribution, and reproduction in any medium, provided the original work is properly cited.

\begin{abstract}
The oxidation of 2-(2-methoxyethoxy)ethanol (MEE) and 2-(2-ethoxyethoxy)ethanol (EEE) by ditelluratocuprate(III) (DTC) had been studied spectrophotometrically in alkaline medium. The reaction between $20^{\circ} \mathrm{C}$ and $40^{\circ} \mathrm{C}$ showed first-order dependence in DTC and fractional order in MEE and EEE. The rate constant $k_{\mathrm{obs}}$ of the pseudo-first-order reaction decreased with an increase of $\left[\mathrm{TeO}_{4}^{2-}\right]$, whereas adding $\left[\mathrm{OH}^{-}\right]$enhanced the constant. In addition, the reaction had a negative salt effect. The rate of EEE was higher than that of MEE. A suitable assumption involving preequilibriums before the rate-controlling step and a free radical mechanism was proposed, based on the kinetic data. Activation parameters and the rate constant of the rate-determining step were calculated.
\end{abstract}

\section{Introduction}

Recently, more and more researchers have devoted themselves to the study of the higher oxidation state of transition metal. $\mathrm{Cu}(\mathrm{III}), \mathrm{Ag}(\mathrm{III})$, and $\mathrm{Ni}(\mathrm{IV})$ can be stabilized by chelation with polydentate ligands, such as ditelluratocuprate(III) $[1,2]$, diperiodatocuprate(III) $[3,4]$, diperiodatoargentate(III) [5, 6], ditelluratoargentate(III) [7], diperiodatonickelate(IV) [8] which are good oxidants in a medium with an appropriate $\mathrm{pH}$. As early as 1844 , the researchers have begun to study $\mathrm{Cu}$ (III) complex. Now, the use of $\mathrm{Cu}$ (III) not only plays a prominent role in many biological systems involving electron-transfer processes, but also makes contribution as an oxidation agent in organic mixture qualitative analysis [9]. Hence, the further research of $\mathrm{Cu}(\mathrm{III})$ is significant. In the present paper, the mechanism of oxidation of 2(2-methoxyethoxy)ethanol and 2-(2-ethoxyethoxy)ethanol by ditelluratocuprate(III) is reported.

Both 2-(2-methoxyethoxy)-ethanol and 2-(2-ethoxyethoxy)-ethanol are colorless liquids and high boiling point solvents so that they have a wide application such as printing, dyeing, resin, cellulose, and coatings. In addition, 2-(2-methoxy ethoxy)-ethanol can be used for the extracting agent for hydrocarbon and chemical reagent in chemical analysis.

\section{Experimental Section}

2.1. Materials. All chemicals used were of AR grade, and double distilled water was used throughout the work. Ditelluratocuprate(III) (DTC) was prepared and standardized by the method reported by Chandra and Yadava [10, 11]. The purity of the complex was checked by comparing UV-Vis spectrum with the literature data, which showed a characteristic absorption peak at $405 \mathrm{~nm} . \mathrm{KNO}_{3}$ and $\mathrm{KOH}$ were used to maintain ionic strength and alkalinity of the reaction, respectively. Besides, solutions of DTC and reductants were always freshly prepared before using.

2.1.1. Kinetics Measurements and Apparatus. The kinetics were followed under pseudo-first-order conditions. Solution $(2 \mathrm{~mL})$ containing required concentration of DTC, $\mathrm{OH}^{-}$, and $\mathrm{TeO}_{4}{ }^{2-}$ and ionic strength and reductant solution $(2 \mathrm{~mL})$ of requisite concentration were transferred separately to the upper and lower branch tubes of a $\lambda$ type two-cell reactor. 
TABLE $1: 10^{3} k_{\text {obs }} / \mathrm{s}^{-1}$ varying with the different [MEE] at different temperatures.

\begin{tabular}{|c|c|c|c|c|c|c|c|c|}
\hline \multirow{2}{*}{$T / K$} & \multicolumn{5}{|c|}{$[\mathrm{MEE}] / \mathrm{mol} \cdot \mathrm{L}^{-1}$} & \multirow[b]{2}{*}{$n_{\mathrm{ap}}$} & \multirow[b]{2}{*}{$r_{1}$} & \multirow[b]{2}{*}{$r_{2}$} \\
\hline & 0.01 & 0.02 & 0.03 & 0.04 & 0.05 & & & \\
\hline 293.2 & 2.25 & 3.89 & 5.84 & 6.86 & 8.28 & 0.18 & 0.998 & 0.998 \\
\hline 298.2 & 3.98 & 6.90 & 9.39 & 10.94 & 13.60 & 0.25 & 0.998 & 0.999 \\
\hline 303.2 & 8.21 & 12.85 & 17.32 & 19.47 & 21.21 & 0.40 & 0.995 & 0.998 \\
\hline 308.2 & 13.75 & 21.12 & 24.72 & 27.87 & 29.71 & 0.52 & 0.991 & 0.999 \\
\hline 313.2 & 22.77 & 31.63 & 37.77 & 40.32 & 43.59 & 0.60 & 0.994 & 0.999 \\
\hline
\end{tabular}

TABLE 2: $10^{3} k_{\mathrm{obs}} / \mathrm{s}^{-1}$ varying with the different [EEE] at different temperatures.

\begin{tabular}{|c|c|c|c|c|c|c|c|c|}
\hline \multirow{2}{*}{$T / \mathrm{K}$} & \multicolumn{5}{|c|}{$[\mathrm{EEE}] / \mathrm{mol} \cdot \mathrm{L}^{-1}$} & \multirow[b]{2}{*}{$n_{\mathrm{ap}}$} & \multirow[b]{2}{*}{$r_{1}$} & \multirow[b]{2}{*}{$r_{2}$} \\
\hline & 0.01 & 0.02 & 0.03 & 0.04 & 0.05 & & & \\
\hline 293.2 & 2.22 & 4.12 & 6.30 & 7.24 & 9.12 & 0.13 & 0.997 & 0.999 \\
\hline 298.2 & 3.95 & 6.54 & 9.70 & 11.61 & 13.95 & 0.15 & 0.999 & 0.999 \\
\hline 303.2 & 5.06 & 9.80 & 13.39 & 15.91 & 18.61 & 0.19 & 0.996 & 0.999 \\
\hline 308.2 & 8.04 & 14.94 & 20.39 & 22.60 & 29.42 & 0.22 & 0.994 & 0.998 \\
\hline 313.2 & 11.64 & 21.07 & 29.65 & 31.76 & 39.31 & 0.25 & 0.992 & 0.998 \\
\hline
\end{tabular}

After thermostating the solutions at the desired temperature, the two solutions rapidly mixed and put into the galss absorption cell. The progress of the reaction was followed by measuring the decrease in absorbance of DTC at $405 \mathrm{~nm}$. The kinetic measurements were performed on a UV-vis spectrophotometer, which had a cell holder kept at constant temperature $\left( \pm 0.1^{\circ} \mathrm{C}\right)$ by circulating water from a thermostat. It was verified that the effect of other reagents at $405 \mathrm{~nm}$ was negligible.

\section{Results and Discussion}

3.1. Stoichiometric and Product Analysis. Stoichiometric studies revealed that $1 \mathrm{~mol}$ of DTC consumed $1 \mathrm{~mol}$ of reductants by adding dropwise DTC of known concentrations to $0.1 \mathrm{~mol} \cdot \mathrm{L}^{-1}$ reductants until no further decolorization was observed [12]

$$
\begin{array}{r}
{\left[\mathrm{Cu}(\mathrm{OH})_{2}\left(\mathrm{H}_{4} \mathrm{TeO}_{6}\right)_{2}\right]^{3-}+\mathrm{HOCH}_{2} \mathrm{CH}_{2} \mathrm{OCH}_{2} \mathrm{CH}_{2} \mathrm{R}+\mathrm{OH}^{-}} \\
\rightleftharpoons \mathrm{Cu}(\mathrm{II})+\mathrm{OCHCH}_{2} \mathrm{OCH}_{2} \mathrm{CH}_{2} \mathrm{R}+\mathrm{H}_{4} \mathrm{TeO}_{6}{ }^{2-}+\mathrm{H}_{2} \mathrm{O}
\end{array}
$$

Under the kinetic conditions, the product of oxidation was identified as an aldehyde by its characteristic spot test [13].

3.2. Evaluation of Pseudo-First-Order Rate Constants. Under the conditions of $[\text { reductant }]_{0}\left([\mathrm{MEE}]_{0}\right.$ and $\left.[\mathrm{EEE}]_{0}\right) \gg$ $[\mathrm{Cu}(\mathrm{III})]_{0}$, the plots of $\ln \left(A_{t}-A_{\infty}\right)$ versus time were straight lines $(r \geq 0.9993)$, indicating the order in DTC to be unity. The pseudo-first-order rate constants $k_{\mathrm{obs}}$ were evaluated by using the equation $\ln \left(A_{t}-A_{\infty}\right)=-k_{\mathrm{obs}} t+b$ (constant).
The $k_{\mathrm{obs}}$ values were the average value of at least three independent experiments, and reproducibility was within $\pm 5 \%$.

3.3. Rate Dependence on the [Reductant]. The [reductant] was varied in the range of $1.00 \times 10^{-2}$ to $5.00 \times 10^{-2} \mathrm{~mol} \cdot \mathrm{L}^{-1}$ at different temperature keeping all other [reactants] constant. The order $n_{\text {ap }}$ in reductant were calculated as fractional order form the slopes of the plots of $\ln k_{\text {obs }}$ versus $\ln$ [reductant] (Tables 1 and 2). Besides, the $k_{\text {obs }}$ value increased with the increasing [reductant]. The plots of $k_{\mathrm{obs}}{ }^{-1}$ versus [reductant] ${ }^{-1}$ were straight lines $(r \geq 0.998)$.

3.4. Rate Dependence on the $[\mathrm{OH}]^{-}$. The effect of $\left[\mathrm{OH}^{-}\right]$ on the reaction had been studied in the range of $5.00 \times$ $10^{-3} \mathrm{~mol} \cdot \mathrm{L}^{-1}$ to $25.00 \times 10^{-3} \mathrm{~mol} \cdot \mathrm{L}^{-1}$ at constant [DTC], [reductant], $\left[\mathrm{TeO}_{4}{ }^{2-}\right.$ ], $\mu$, and temperature (Table 3). It was found that $k_{\mathrm{obs}}$ values increased with the increasing $\left[\mathrm{OH}^{-}\right]$ and the order with respect to $\left[\mathrm{OH}^{-}\right]$was fractional. The plot of $k_{\mathrm{obs}}{ }^{-1}$ versus $\left[\mathrm{OH}^{-}\right]^{-1}$ was linear with a positive intercept $(r \geq 0.999)$.

3.5. Rate Dependence on the $\left[\mathrm{TeO}_{4}{ }^{2-}\right]$. The $\left[\mathrm{TeO}_{4}{ }^{2-}\right]$ was varied from $0.50 \times 10^{-3} \mathrm{~mol} \cdot \mathrm{L}^{-1}$ to $2.50 \times 10^{-3} \mathrm{~mol} \cdot \mathrm{L}^{-1}$ range at constant [DTC], [reductant], $\left[\mathrm{OH}^{-}\right], \mu$, and temperature (Table 3 ). The $k_{\text {obs }}$ increased with the decreasing concentration of $\mathrm{TeO}_{4}{ }^{2-}$. The order with respect to $\mathrm{TeO}_{4}{ }^{2-}$ was found to be a negative fraction, which revealed that $\mathrm{TeO}_{4}{ }^{2-}$ was produced in equilibrium before the rate-controlling step. In addition, the plot of $k_{\mathrm{obs}}{ }^{-1}$ versus $\left[\mathrm{TeO}_{4}{ }^{2-}\right]$ was also straight line with a positive intercept $(r \geq 0.998)$. 
TABLE 3: Effect of $\left[\mathrm{OH}^{-}\right],\left[\mathrm{TeO}_{4}{ }^{2-}\right]$, and $\mu$ on the reaction at $298.2 \mathrm{~K}$.

\begin{tabular}{|c|c|c|c|c|c|c|}
\hline $\begin{array}{l}0^{5}[\mathrm{DTC}] \\
\left(\mathrm{mol} \cdot \mathrm{L}^{-1}\right)\end{array}$ & $\begin{array}{c}\text { [Reductant] } \\
\left(\mathrm{mol} \cdot \mathrm{L}^{-1}\right)\end{array}$ & $\begin{array}{c}\mu \times 10^{2} \\
\left(\mathrm{~mol} \cdot \mathrm{L}^{-1}\right)\end{array}$ & $\begin{array}{c}10^{3}\left[\mathrm{TeO}_{4}{ }^{2-}\right] \\
\left(\mathrm{mol} \cdot \mathrm{L}^{-1}\right)\end{array}$ & $\begin{array}{c}10^{3}\left[\mathrm{OH}^{-}\right] \\
\left(\mathrm{mol} \cdot \mathrm{L}^{-1}\right)\end{array}$ & $\begin{array}{c}\text { MEE } \\
10^{3} k_{\mathrm{obs}} / \mathrm{s}^{-1}\end{array}$ & $\begin{array}{c}\text { EEE } \\
10^{3} k_{\mathrm{obs}} / \mathrm{s}^{-1}\end{array}$ \\
\hline 7.16 & 0.03 & 3.80 & 1.00 & 5.00 & 7.17 & 8.20 \\
\hline 7.16 & 0.03 & 3.80 & 1.00 & 10.00 & 7.94 & 9.69 \\
\hline 7.16 & 0.03 & 3.80 & 1.00 & 15.00 & 8.27 & 10.18 \\
\hline 7.16 & 0.03 & 3.80 & 1.00 & 20.00 & 8.45 & 10.68 \\
\hline 7.16 & 0.03 & 3.80 & 1.00 & 25.00 & 8.53 & 10.86 \\
\hline 7.16 & 0.03 & 3.80 & 0.50 & 2.50 & 9.49 & 13.24 \\
\hline 7.16 & 0.03 & 3.80 & 1.00 & 2.50 & 7.13 & 10.14 \\
\hline 7.16 & 0.03 & 3.80 & 1.50 & 2.50 & 5.84 & 7.54 \\
\hline 7.16 & 0.03 & 3.80 & 2.00 & 2.50 & 4.90 & 6.73 \\
\hline 7.16 & 0.03 & 3.80 & 2.50 & 2.50 & 4.27 & 5.86 \\
\hline 7.16 & 0.03 & 1.50 & 1.00 & 2.50 & 8.89 & 12.34 \\
\hline 7.16 & 0.03 & 3.00 & 1.00 & 2.50 & 7.56 & 9.61 \\
\hline 7.16 & 0.03 & 4.50 & 1.00 & 2.50 & 7.03 & 9.17 \\
\hline 7.16 & 0.03 & 6.00 & 1.00 & 2.50 & 6.45 & 8.68 \\
\hline 7.16 & 0.03 & 7.50 & 1.00 & 2.50 & 5.19 & 7.66 \\
\hline
\end{tabular}

3.6. Rate Dependence on the Ionic Strength $\mu$. The effect of ionic strength on the reaction was studied from 1.50 $\times 10^{-2} \mathrm{~mol} \cdot \mathrm{L}^{-1}$ to $7.50 \times 10^{-2} \mathrm{~mol} \cdot \mathrm{L}^{-1}$ at constant [DTC], [reductant], $\left[\mathrm{OH}^{-}\right],\left[\mathrm{TeO}_{4}{ }^{2-}\right]$, and temperature (Table 3). The experimental results indicated that the rate constant decreased with the increasing $\mu$ which showed that there was negative salt which was consistent with the common regulation of the kinetics [14].

3.7. Free Radical Detection. To study the possible presence of a free radical during the reaction, a known amount of acrylamide was added under the protection of nitrogen atmosphere. The polymerization clearly appeared which indicated that free radical intermediates might be produced in the oxidation by DTC. And blank experiments in reaction system gave no polymeric suspensions.

3.8. Reaction Mechanism. In the alkaline medium, the electric dissociation equilibrium of telluric acid was given earlier (here $\mathrm{pK}_{w}=14$ )

$$
\begin{gathered}
\mathrm{H}_{5} \mathrm{TeO}_{6}{ }^{-}+\mathrm{OH}^{-} \rightleftharpoons \mathrm{H}_{4} \mathrm{TeO}_{6}{ }^{2-}+\mathrm{H}_{2} \mathrm{O}, \quad \lg \beta_{1}=3.049 \\
\mathrm{H}_{4} \mathrm{TeO}_{6}{ }^{2-}+\mathrm{OH}^{-} \rightleftarrows \mathrm{H}_{3} \mathrm{TeO}_{6}{ }^{3-}+\mathrm{H}_{2} \mathrm{O}, \quad \lg \beta_{2}=-1
\end{gathered}
$$

Hence, the main tellurate species was $\mathrm{H}_{4} \mathrm{TeO}_{6}{ }^{2-}$ in the concentration of $\mathrm{OH}^{-}$range used in this work.

The fractional order in $\mathrm{OH}^{-}$determined that $\mathrm{OH}^{-}$ took part in a preequilibrium with $\mathrm{Cu}$ (III) before the ratedetermining step. The plot of $k_{\mathrm{obs}}{ }^{-1}$ versus $\left[\mathrm{TeO}_{4}{ }^{2-}\right]$ was straight line with a positive intercept indicating a dissociation equilibrium in which the $\mathrm{Cu}$ (III) lost a tellurate ligand $\mathrm{H}_{4} \mathrm{TeO}_{6}{ }^{2-}$ from its coordination sphere forming an active species monotelluratocuprate(III) complex (MTC). The order with respect to reductant was fractional, which indicated complex formation between reductant and MTC. In addition, the plot of $k_{\mathrm{obs}}{ }^{-1}$ versus [reductant] ${ }^{-1}$ was straight line with a positive intercept proving the kinetic evidence for the formation of $2: 1$ complex.

In alkaline solution studied, $\left(\mathrm{H}_{2} \mathrm{TeO}_{6}\right)_{4}{ }^{-}$protonated easily and coordinated with central ion formed $\left[\mathrm{Cu}\left(\mathrm{H}_{4} \mathrm{TeO}_{6}\right)_{2}\right]^{-}$. The plausible mechanism of oxidation was proposed as follows ( $\mathrm{R}$, resp. stand for $\mathrm{OCH}_{3}$ and $\mathrm{OCH}_{2} \mathrm{CH}_{3}$ ):

$$
\begin{aligned}
& {\left[\mathrm{Cu}\left(\mathrm{H}_{4} \mathrm{TeO}_{6}\right)_{2}\right]^{-}+\mathrm{OH}^{-}} \\
& \stackrel{k_{1}}{\rightleftharpoons}\left[\mathrm{Cu}\left(\mathrm{H}_{3} \mathrm{TeO}_{6}\right)\right]+\mathrm{H}_{4} \mathrm{TeO}_{6}{ }^{2-}+\mathrm{H}_{2} \mathrm{O} \\
& {\left[\mathrm{Cu}\left(\mathrm{H}_{3} \mathrm{TeO}_{6}\right)\right]+\mathrm{HOCH}_{2} \mathrm{CH}_{2} \mathrm{OCH}_{2} \mathrm{CH}_{2} \mathrm{R}} \\
& \quad \stackrel{k_{2}}{\rightleftharpoons}\left[\mathrm{Cu}\left(\mathrm{H}_{3} \mathrm{TeO}_{6}\right)\left(\mathrm{HOCH}_{2} \mathrm{CH}_{2} \mathrm{OCH}_{2} \mathrm{CH}_{2} \mathrm{R}\right)\right] \\
& {\left[\mathrm{Cu}\left(\mathrm{H}_{3} \mathrm{TeO}_{6}\right)\left(\mathrm{HOCH}_{2} \mathrm{CH}_{2} \mathrm{OCH}_{2} \mathrm{CH}_{2} \mathrm{R}\right)\right]} \\
& \stackrel{{ }_{\text {slow }}}{\longrightarrow} \mathrm{Cu}(\mathrm{II})+{ }^{\circ} \mathrm{CH}_{(\mathrm{HO}) \mathrm{CH}_{2} \mathrm{OCH}_{2} \mathrm{CH}_{2} \mathrm{R}+\mathrm{H}^{+}} \\
& \stackrel{{ }^{\circ} \mathrm{CH}}{\stackrel{\mathrm{HO}_{f}}{\longrightarrow}} \mathrm{CH}_{2} \mathrm{OCH}_{2} \mathrm{OCH}_{2} \mathrm{R}+\mathrm{Cu}^{*}(\mathrm{III})
\end{aligned}
$$

The $\mathrm{Cu}^{*}$ (III) stands for any kind of which $\mathrm{Cu}^{3+}$ existed in equilibrium. The total concentration of $\mathrm{Cu}(\mathrm{III})$ at time $t$ can be written as

$$
\begin{aligned}
{[\mathrm{Cu}(\mathrm{III})]_{t}=} & {\left[\mathrm{Cu}\left(\mathrm{H}_{4} \mathrm{TeO}_{6}\right)_{2}\right]_{\mathrm{e}}^{-}+\left[\mathrm{Cu}\left(\mathrm{H}_{3} \mathrm{TeO}_{6}\right)\right]_{\mathrm{e}} } \\
& +\left[\mathrm{Cu}\left(\mathrm{H}_{3} \mathrm{TeO}_{6}\right)\left(\mathrm{HOCH}_{2} \mathrm{CH}_{2} \mathrm{OCH}_{2} \mathrm{CH}_{2} \mathrm{R}\right)\right]_{\mathrm{e}}
\end{aligned}
$$


TABLE 4: Rate constants $(k)$ and activation parameters of the rate-determining step.

\begin{tabular}{lcccccc}
\hline \multicolumn{1}{c}{$T(\mathrm{~K})$} & & 293.3 & 298.2 & 303.2 & 308.2 & 313.2 \\
\hline $10^{2} \mathrm{k} / \mathrm{s}^{-1}$ & MEE & 1.16 & 1.48 & 1.78 & 2.11 & 2.77 \\
& EEE & 1.92 & 2.49 & 3.12 & 3.79 \\
\hline Thermodynamic activation & MEE & $E_{\mathrm{a}} /\left(\mathrm{kJ} \cdot \mathrm{mol}^{-1}\right)=32.11, \Delta H^{\neq} /\left(\mathrm{kJ} \cdot \mathrm{mol}^{-1}\right)=29.63$, and $\Delta S^{\neq} /\left(\mathrm{J} \cdot \mathrm{K}^{-1} \cdot \mathrm{mol}^{-1}\right)=-142.52$ \\
parameters & EEE & $E_{\mathrm{a}} /\left(\mathrm{kJ} \cdot \mathrm{mol}^{-1}\right)=31.01, \Delta H^{\neq} /\left(\mathrm{kJ} \cdot \mathrm{mol}^{-1}\right)=28.53$, and $\Delta S^{\neq} /\left(\mathrm{J} \cdot \mathrm{K}^{-1} \cdot \mathrm{mol}^{-1}\right)=-141.86$ \\
\hline
\end{tabular}

The plots of $\ln k$ versus $1 / T$ has the following: intercept (a), slope (b), and relative coefficient $(r)$.

MEE: $a=13.32, b=-3863.18$, and $r=-0.996$; EEE: $a=13.41, b=-3730.92$, and $r=-0.993$.

Since reaction (6) was the rate-determining step, the rate of disappearance of $[\mathrm{Cu}(\mathrm{III})]_{t}$ was represented as

$$
\begin{aligned}
- & \frac{\mathrm{d}[\mathrm{Cu}(\mathrm{III})]_{t}}{\mathrm{dt}} \\
= & \frac{2 k K_{1} \mathrm{~K}_{2}\left[\mathrm{OH}^{-}\right]\left[\mathrm{RCH}_{2} \mathrm{CH}_{2} \mathrm{OCH}_{2} \mathrm{CH}_{2} \mathrm{OH}\right]}{\left[\mathrm{H}_{4} \mathrm{TeO}_{6}{ }^{2-}\right]+K_{1}\left[\mathrm{OH}^{-}\right]+K_{1} K_{2}\left[\mathrm{OH}^{-}\right]\left[\mathrm{RCH}_{2} \mathrm{CH}_{2} \mathrm{OCH}_{2} \mathrm{CH}_{2} \mathrm{OH}\right]} \\
& \times[\mathrm{Cu}(\mathrm{III})]=k_{\text {obs }}[\mathrm{Cu}(\mathrm{III})] .
\end{aligned}
$$

Rearranging (9) leads to

$$
\begin{aligned}
\frac{1}{k_{\mathrm{obs}}}= & \frac{1}{2 k}+\frac{\left[\mathrm{H}_{4} \mathrm{TeO}_{6}{ }^{2-}\right]+K_{1}\left[\mathrm{OH}^{-}\right]}{2 k K_{1} \mathrm{~K}_{2}\left[\mathrm{OH}^{-}\right]} \\
& \times \frac{1}{\left[\mathrm{RCH}_{2} \mathrm{CH}_{2} \mathrm{OCH}_{2} \mathrm{CH}_{2} \mathrm{OH}\right]}, \\
\frac{1}{k_{\mathrm{obs}}}= & \frac{1}{2 k}+\frac{1}{2 k K_{2}\left[\mathrm{RCH}_{2} \mathrm{CH}_{2} \mathrm{OCH}_{2} \mathrm{CH}_{2} \mathrm{OH}\right]} \\
& +\frac{\left[\mathrm{H}_{4} \mathrm{TeO}_{6}{ }^{2-}\right]}{2 k K_{1} K_{2}\left[\mathrm{RCH}_{2} \mathrm{CH}_{2} \mathrm{OCH}_{2} \mathrm{CH}_{2} \mathrm{OH}\right]} \times \frac{1}{\left[\mathrm{OH}^{-}\right]} .
\end{aligned}
$$

Equation (9) suggested that the order with respect to $\mathrm{Cu}$ (III) was unity. From (10), the rate constants of the ratedetermining step at different temperature were determined by the intercept of the plots $k_{\mathrm{obs}}{ }^{-1}$ versus [reductant] ${ }^{-1}$ which were straight lines. Hence, the activation energy and the thermodynamic parameters were evaluated by the method given earlier at $298.2 \mathrm{~K}$ (Table 4). In addition, (11) indicated that the plots of $k_{\mathrm{obs}}{ }^{-1}$ versus $\left[\mathrm{OH}^{-}\right]^{-1}$ and $k_{\mathrm{obs}}{ }^{-1}$ versus $\left[\mathrm{H}_{4} \mathrm{TeO}_{6}{ }^{2-}\right]$ were also straight lines. All of the previous conclusions were consistent with experimental results.

\section{Conclusion}

Through the comparative study of oxidation of 2-(2methoxy ethoxy)-ethanol (MEE) and 2-(2-ethoxyethoxy)ethanol(EEE) by ditelluratocuprate(III), we found that both the MEE and the EEE formed the same intermediate compounds with $\mathrm{Cu}(\mathrm{III})$. In addition, the values of the activation parameters with respect to MEE were larger than those of EEE, which indicated that the reactivity of EEE was higher than that of MEE. The reason was that the electron-donating ability of EEE was larger than that of MEE, which indicated that the former was more stable than the latter. The previous conclusions were consistent with experimental results.

\section{References}

[1] J. H. Shan, L. P. Wang, S. G. Shen, and H. W. Sun, "Kinetics and mechanism of oxidation of some hydroxy butyric acid salts by ditelluratocuprate(III) in alkaline medium," Turkish Journal of Chemistry, vol. 27, no. 2, pp. 265-272, 2003.

[2] J. Shan, Y. Liu, and J. Zhang, "Kinetics and mechanism of oxidation of 1-methoxy-2-propanol and 1-ethoxy-2-propanol by Ditelluratocuprate(III) in alkaline medium," Chinese Journal of Chemistry, vol. 29, no. 4, pp. 639-642, 2011.

[3] K. M. Naik and S. T. Nandibewoor, "Kinetic and mechanistic study of oxidation of succinamide by diperiodatocuprate(III) in aqueous alkaline medium," Oxidation Communications, vol. 35, no. 3, pp. 545-559, 2012.

[4] K. M. Naik and S. T. Nandibewoor, "Thermodynamic quantities for different steps involved in the mechanism of the oxidation of 6-mercaptopurine by diperiodatocuprate (III) in aqueous alkaline medium," Journal of Sulfur Chemistry, vol. 32, no. 2, pp. 123-136, 2011.

[5] R. R. Hosamani, N. P. Shetti, and S. T. Nandibewoor, "Mechanistic investigation on the oxidation of ampicillin drug by diperiodatoargentate (iii) in aqueous alkaline medium," Journal of Physical Organic Chemistry, vol. 22, no. 3, pp. 234-240, 2009.

[6] J. I. Gowda, S. R. Sataraddi, and S. T. Nandibewoor, "Oxidation of xylitol by a silver(III) periodate complex in the presence of osmium(VIII) as a homogeneous catalyst," Catalysis Science of Technology, vol. 2, no. 12, pp. 2549-2557, 2012.

[7] J. H. Shan, S. Y. Huo, S. G. Shen, and H. W. Sun, "Kinetics and mechanism of the oxidation of polyhydric alcohols by dihydroxyditelluratoargentate(III) in alkaline medium," Journal of the Serbian Chemical Society, vol. 70, no. 4, pp. 585-592, 2005.

[8] J. H. Shan, H. X. Shen, H. Y. Wang, and X. Q. Wang, "Kinetics and mechanism of oxidation of L-lysine and L-ornithine by dihydroxydiperiodatonickelate (IV) in alkaline liquids," Oxidation Communications, vol. 35, no. 3, pp. 583-590, 2012.

[9] K. B. Reddy, B. Sethuram, and T. N. Rao, "Kinetics and mechanism of Os(VIII) catalysed and uncatalysed oxidation ofcyclopentanol, cyclohexanol and cycloheptanol by ditelluratocuprate(III) in alkaline medium," Indian Journal of Chemistry, vol. 20A, pp. 272-275, 1981.

[10] S. Chandra and K. L. Yadava, "Oxidation of some sugars with copper(III)," Talanta, vol. 15, no. 3, pp. 349-352, 1968.

[11] P. K. Jaiswal and K. L. Yadava, "Determination of sugars and organic acids with periodato comples of $\mathrm{Cu}(\mathrm{III})$," Indian Journal of Chemistry, vol. 11, pp. 837-838, 1973. 
[12] C. P. Murthy, B. Sethuram, and N. T. Rao, "kinetics of oxidation of formaldehyde, acetaldehyde, propionaldehyde and butyraldehyde by ditelhtratocuprate (III) in alkaline medium," Indian Journal of Chemistry, vol. 17A, pp. 48-51, 1979.

[13] F. Feigl, Spot Tests in Organic Anaiysis, Elsevier, New York, NY, USA, 1966.

[14] J. Jin, Kinetics Principle of Chemical Reaction in Liquid Phase, Science Technique Press, Shanghai, China, 1966. 

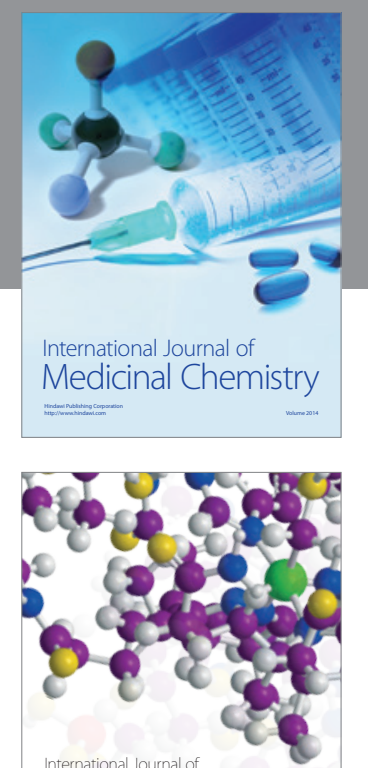

\section{Carbohydrate} Chemistry

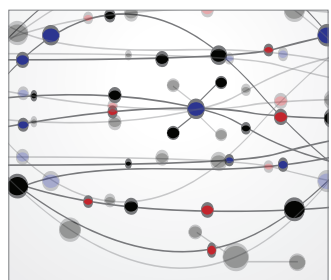

The Scientific World Journal
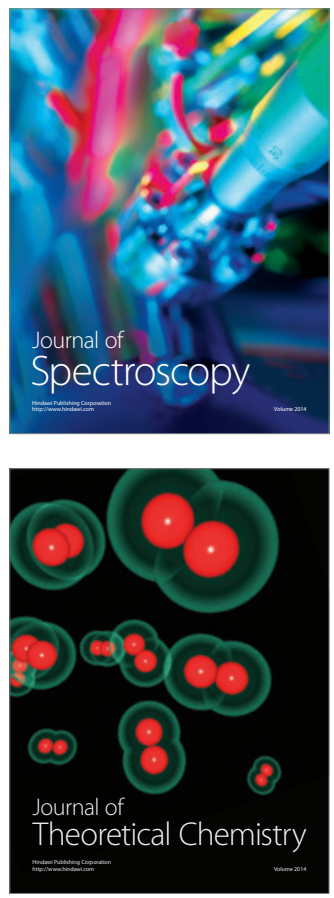
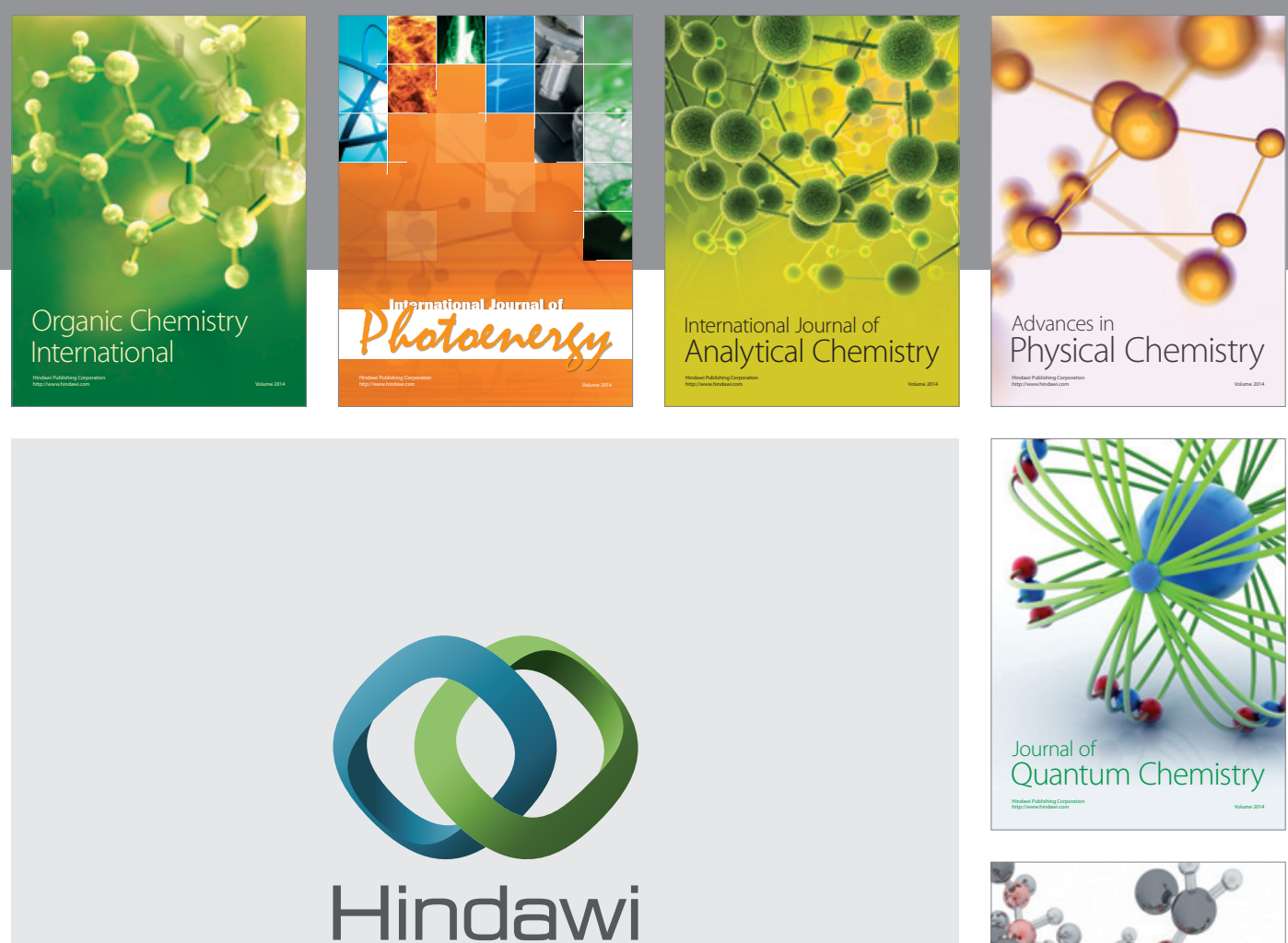

Submit your manuscripts at

http://www.hindawi.com

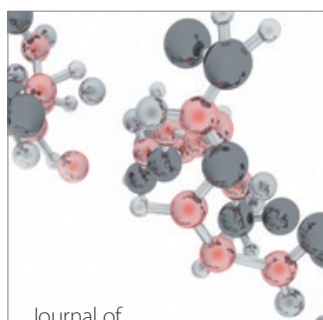

Analytical Methods

in Chemistry

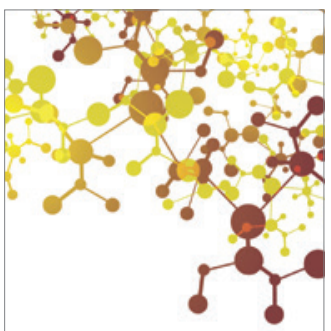

Journal of

Applied Chemistry

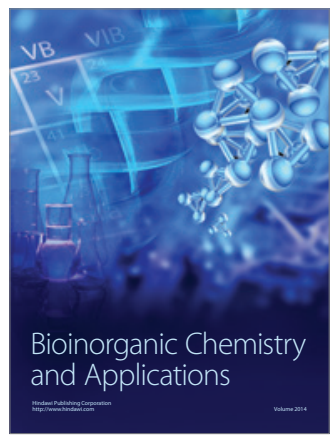

Inorganic Chemistry
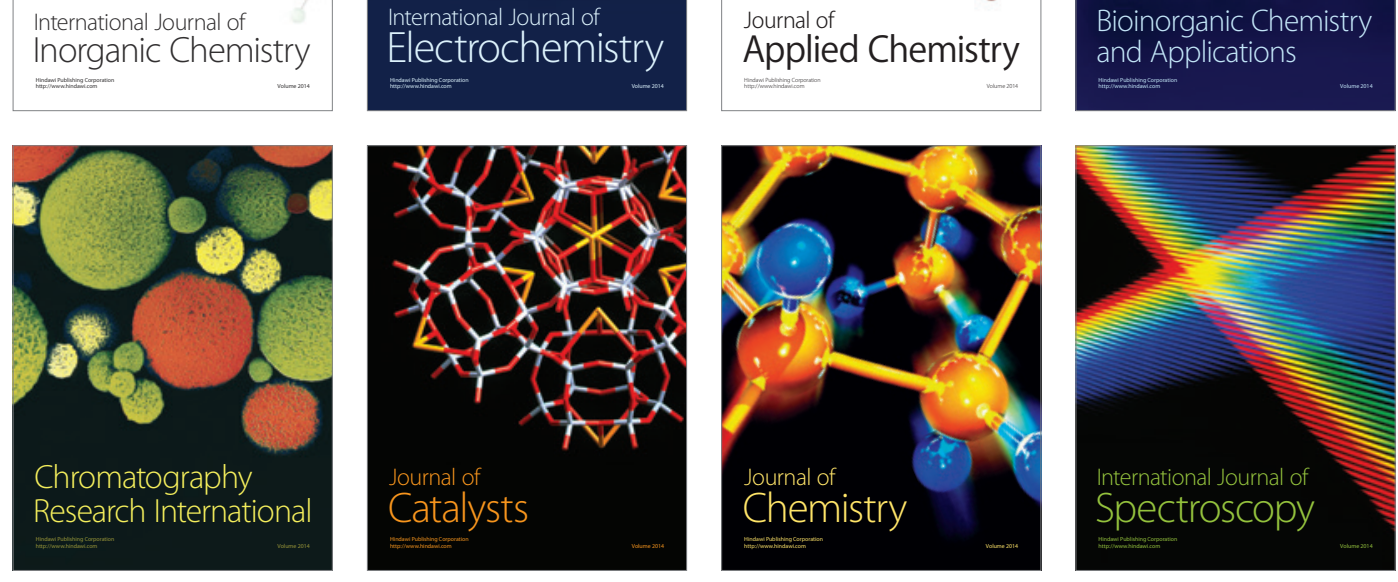